\title{
Effects of Hydraulic Retention Time (HRT) and Packing Height on the Performance of Homemade Ceramsite-Soil Constructed Wetland for Rural Domestic Wastewater Treatment
}

\author{
Xinyan Zhang ${ }^{1}$, Xuan $\mathrm{Li}^{1}$, Qingji Han ${ }^{2}$, Kai Ju' ${ }^{1}$, Dongyang Wei ${ }^{3}$, \\ Yongqing Sun ${ }^{1}$, Qiong Wan ${ }^{1 *}$ \\ ${ }^{1}$ School of Architecture and Civil Engineering, Xi' an University of Science and Technology, Xi'an710054, China \\ ${ }^{2}$ Xi'an Research and Design Institute of Wall \& Roof Materials Co., Ltd., Xi'an 710061, China \\ ${ }^{3}$ Environment Development Centre, Ministry of Ecology and Environment, Beijing 100029, China
}

Received: 25 November 2020

Accepted: 11 February 2021

\begin{abstract}
In this study, homemade ceramsite-soil filler (system A) and a simple soil filler (system B) were applied in vertical upflow constructed wetlands, and their performance in the treatment of rural domestic wastewater were investigated under various HRTs and packing heights. Optimum performance was reached at a HRT of $6.4 \mathrm{~d}$ in both systems. The average removal rates of ammonia nitrogen $\left(\mathrm{NH}_{4}{ }^{+} \mathrm{N}\right)$, total nitrogen (TN), and total phosphorus (TP) in system A were as high as 90.78, 86.04, and 90.15\%, respectively, which were $0.94,2.21$, and $10.62 \%$ higher than those in system $\mathrm{B}$. The $\mathrm{TN}$ and $\mathrm{NH}_{4}^{+}-\mathrm{N}$ removal efficiencies of both systems decreased with shorter HRTs, whereas the TP removal efficiency was almost not affected. Along the inlet direction, with increasing packing height, the pollutant removal capacity gradually decreased, and the $\mathrm{NH}_{4}^{+}-\mathrm{N}$ removal efficiencies in the bottom layers (0-145 mm) of system A and B were 55.88 and $50.22 \%$, respectively, with $\mathrm{NH}_{4}^{+}-\mathrm{N}$ volumetric loads of 8.63 and $7.76 \mathrm{~g} /\left(\mathrm{m}^{3} \cdot \mathrm{d}\right)$. System A contained more nitrifying genera at the genus level, mainly including Stenotrophomonas, Sphingomonas, and Acinetobacter. The addition of ceramsite resulted in a higher treatment efficiency and resistance to hydraulic shock loading.
\end{abstract}

Keywords: HRT, packing height, ceramsite, constructed wetland, rural domestic wastewater

*e-mail: wq6675@xust.edu.cn 


\section{Introduction}

In China, the annual production of rural domestic wastewater is about 8 billion $\mathrm{m}^{3}$, but the current sewage treatment infrastructure is inadequate. Throughout the country, $96 \%$ of the villages have no drainage pipes and sewage treatment systems [1], resulting in the direct discharge of sewage and, consequently, the deterioration of surface water quality [2]. Constructed wetlands $(\mathrm{CWs})$ represent sewage treatment systems that integrate physical, chemical, and biological reactions [3]. Compared with other wastewater treatment approaches, treatment in such wetlands has the advantages of low technical requirements, strong sustainability, high nutrient removal rates, and low operating costs [46]. Although CWs take up large areas [7], they can be designed flexibly according to the amount of sewage; alternatively, they can be decentralized in accordance with aesthetic characteristics of a landscape. Constructed wetlands are particularly suitable for the treatment of rural wastewater with unstable quantity.

HRT is one of the important operation parameters of a CW system and related to the contact degree of sewage and wetland. To improve the performance of $\mathrm{CWs}$, different procedures have been used, with the aim to optimize the HRT. For example, the removal rates of $\mathrm{NH}_{4}^{+}-\mathrm{N}, \mathrm{NO}_{3}^{-}-\mathrm{N}$, and phosphate increase with increasing HRTs [8-11]. However, an excessively prolonged HRT results in a large occupied area and, in some cases, in system failure. Different reactor configurations and influent substrates may result in different suitable HRTs. Therefore, the optimal HRT of a system is important to reduce the area occupied by $\mathrm{CWs}$ and to achieve maximum pollutant removal rates. In this sense, it is of great practical significance to explore the suitability of the HRT for CWs with new filler material.

The filler material plays a crucial role in CWs as it is the matrix in which most biochemical reactions occur. In recent years, there have been numerous reports on the development and application of conventional (gravel, zeolite, and biochar, etc.) and new filler materials (sponge iron, plastic, and solid waste, etc.) [12-15]. To further reveal the removal efficiency and purification mechanisms in CWs, it is important to investigate various pollutant concentrations at different packing heights. Xia et al. (2020) have investigated the changes in pollutant concentrations at different packing heights in a vertical downflow constructed wetland and showed that the top aerobic zones play a major role in the removal of $\mathrm{COD}, \mathrm{NH}_{4}^{+}-\mathrm{N}$, and TP [16]. In the upflow constructed wetland developed by Wang et al., due to abundant nutrients in the influent and high microbial reproduction, most TP was removed at the bottom layer $(0-30 \mathrm{~cm})$, with removal rates of up to $50 \%$ [17].

In this context, we explored the pollutant removal performance and interspecific interactions in a verticalflow constructed wetland (VFCW) with a homemade ceramsite-soil filler. The effects of different HRTs on pollutant removal and the distribution of pollutant removal were described and analyzed. The microbial communities along the vertical direction in both systems were analyzed using 16S rRNA gene sequencing, with the aim to determine the effect of homemade ceramsite on the microbial community structure. It is hoped that this study will provide reliable technical support for the treatment of rural domestic wastewater in constructed wetlands.

\section{Materials and Methods}

\section{Materials}

We used domestic sewage from a drainage well in a residential district of Guangzhou as influent; the composition of this sewage is shown in Table 1. The ceramsite was prepared by an optimized combination of drinking waterworks sludge, coal fly ash, clay and glass powder. Specific preparation methods are described in the earlier literature of this research group [18]. The soil was obtained from Nansha Wetland Park in

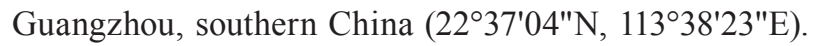
After 4 months of cultivation, mature Bruguiera plants (about $30 \mathrm{~g} /$ plant) of the same size were selected and transplanted into the $\mathrm{CW}$ system. The plants were obtained from Huangpu Flower Market in Guangzhou, southern China $\left(23^{\circ} 07^{\prime} 10^{\prime \prime} \mathrm{N}, 113^{\circ} 27^{\prime} 46^{\prime \prime} \mathrm{E}\right)$.

\section{CW Configuration and Operation}

Fig. 1 shows the dimensions and structure of the CW. The system was built of organic glass with diameter $\times$ height of $19 \times 45 \mathrm{~cm}$. Total effective volume and effective water volume were 12.3 and $6.3 \mathrm{~L}$, respectively, and the experiment was partitioned into Group A and Group B. The filler in A was a homogeneous mix of wetland soil and homemade ceramsite at a volume ratio of $1: 1$; in the control (Group B), we used wetland soil. The planting density of both groups was 3 plants $/ 0.12 \mathrm{~m}^{2}$. There were five sampling ports, and the heights from the bottom (serial number) were 8.0 (A1, B1), 14.5 (A2, B2), 21.0 (A3, B3), 27.5 (A4, B4), and 34.0 (A5, B5) cm, respectively. For uniform water

Table 1. Experimental influent water quality.

\begin{tabular}{|c|c|c|c|c|c|c|c|}
\hline $\begin{array}{c}\text { Water quality } \\
\text { index }\end{array}$ & $\begin{array}{c}\mathrm{NH}_{4}^{+}-\mathrm{N} \\
\left(\mathrm{mg} \cdot \mathrm{L}^{-1}\right)\end{array}$ & $\begin{array}{c}\mathrm{TN} \\
\left(\mathrm{mg} \cdot \mathrm{L}^{-1}\right)\end{array}$ & $\begin{array}{c}\mathrm{TP} \\
\left(\mathrm{mg} \cdot \mathrm{L}^{-1}\right)\end{array}$ & $\begin{array}{c}\mathrm{TOC} \\
\left(\mathrm{mg} \cdot \mathrm{L}^{-1}\right)\end{array}$ & $\begin{array}{c}\mathrm{DO} \\
\left(\mathrm{mg} \cdot \mathrm{L}^{-1}\right)\end{array}$ & $\begin{array}{c}\text { Temperature } \\
\left({ }^{\circ} \mathrm{C}\right)\end{array}$ & $\mathrm{pH}$ \\
\hline Numerical value & $44.96 \pm 5.80$ & $68.45 \pm 11.53$ & $11.36 \pm 2.35$ & $29.53 \pm 13.45$ & $2.20 \pm 0.28$ & $16 \sim 22$ & $6.7 \sim 8.3$ \\
\hline
\end{tabular}




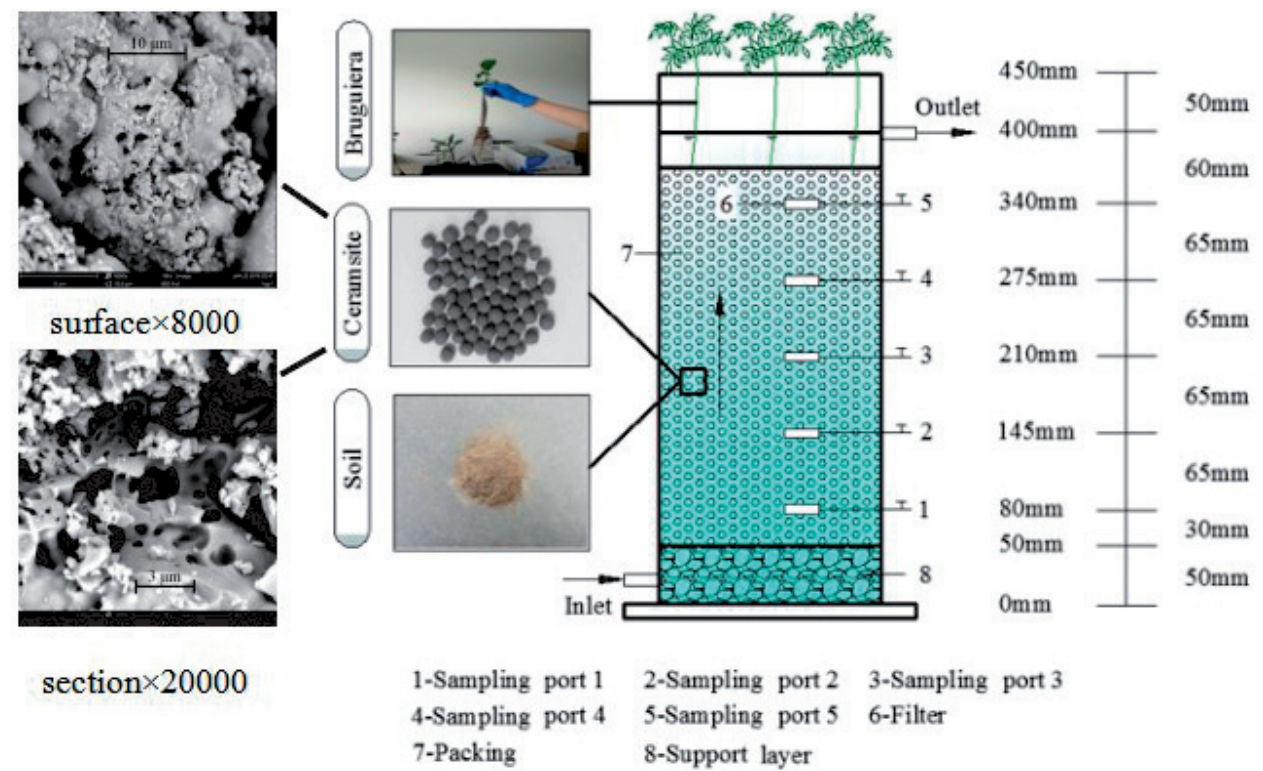

Fig. 1. Schematic diagram of the CW system.

distribution and to inhibit short flow, a $5-\mathrm{cm}$ gravel (diameter of 9-12 $\mathrm{mm}$ ) supporting layer was placed at the bottom of the column. The water level was kept at a height of $3 \mathrm{~cm}$ above the top of the filler.

In practical engineering applications, on the premise that the effluent quality meets the discharge standard, the pursuit of the shortest possible HRT can effectively save costs and operating expenses. Previous studies have shown that maximum pollutant removal efficiency can be achieved at the HRT of 4-15 days [9]. Therefore, $6.4,3.5$, and $1.5 \mathrm{~d}$ were chosen as the experimental HRTs in this study, in an attempt to find shorter HRTs and investigate the metabolism of pollutant degradation. It may provide technical reference for the optimisation of the process. The experiment was run for 71 days in three phases: days 1-20 for the first phase $($ HRT $=6.4 \mathrm{~d})$, days 21-45 for the second phase (HRT $=3.5 \mathrm{~d}$ ), and days 46-71 for the third phase $($ HRT $=1.5 \mathrm{~d}$ ). During the experiment, the outside ambient temperature was kept constant at $25^{\circ} \mathrm{C}$ through a central air conditioning system.

\section{Analytical Methods}

Samples were taken at the inlet and outlet every 5 days and at each sampling outlet on day 11. To determine $\mathrm{NH}_{4}^{+}-\mathrm{N}$ and TP levels, we used standard methods [19]; TN was determined by a TOC/TN analyzer (TOC-L CPH CN200, SHIMADZU, Japan). A portable DO meter (STARTER-300D, OHAUS, USA), a pH meter (STARTER-300D, OHAUS, USA), and a thermometer were used to determine the $\mathrm{DO}, \mathrm{pH}$, and temperature values, respectively, of the influent water.

\section{Microbial Community Analysis}

At the end of the experiment, the biofilms of both reactors at the sampling ports 1,3 , and 5 (lower layer:
A1, B1, middle layer: A3 and B3, upper layer: A5 and B5) were analyzed to determine the microbial community. Total DNA extraction was performed using Hipure Soil DNA Kits (Magen, China) according to the manufacturer's instructions. The V4 region of the $16 \mathrm{~S}$ rRNA gene was amplified by PCR using the primers $515 \mathrm{~F}$ and 806R (515F: 5'-GTGCCAGCMGCCGCGGTAA-3', 806R: 5'-GGACTACHVGGGTWTCTAAT-3') [20]. Two groups of samples were sequenced with the Illumina Hiseq reactor by Beijing Novogene Biological Information Technology Co., Ltd. (Beijing, China).

\section{Results and Discussion}

\section{Effects of HRT on Nitrogen Removal}

The variations in effluent nitrogen concentration in both systems and at different HRTs are shown in Fig. 2 (a-b). In both systems, effluent $\mathrm{N}$ concentrations increased with shorter HRTs, similar to the levels of $\mathrm{NH}_{4}^{+}$-N. Compared with system B, system A showed a better nitrogen removal performance.

At a HRT of $6.4 \mathrm{~d}$, the average removal rates of $\mathrm{NH}_{4}{ }^{+}-\mathrm{N}$ and $\mathrm{TN}$ in system A were 90.78 and $86.04 \%$, which were 0.94 and $2.21 \%$ higher than those in system B. Both systems maintained high levels of nitrogen removal performance. On the one hand, in both systems, the microorganisms had sufficient time to interact with nitrogen. On the other hand, atmospheric reoxygenation and oxygen delivery by plant roots resulted in higher DO levels for nitrifying bacteria. The nitrogen removal rate decreased to the minimum value on day 31 (HRT of $3.5 \mathrm{~d}$ ) in the second phase, most likely because of the increase in influent nitrogen and organic load, intensifying the competition for DO between nitrifying bacteria and heterotrophic bacteria. When the HRT was 

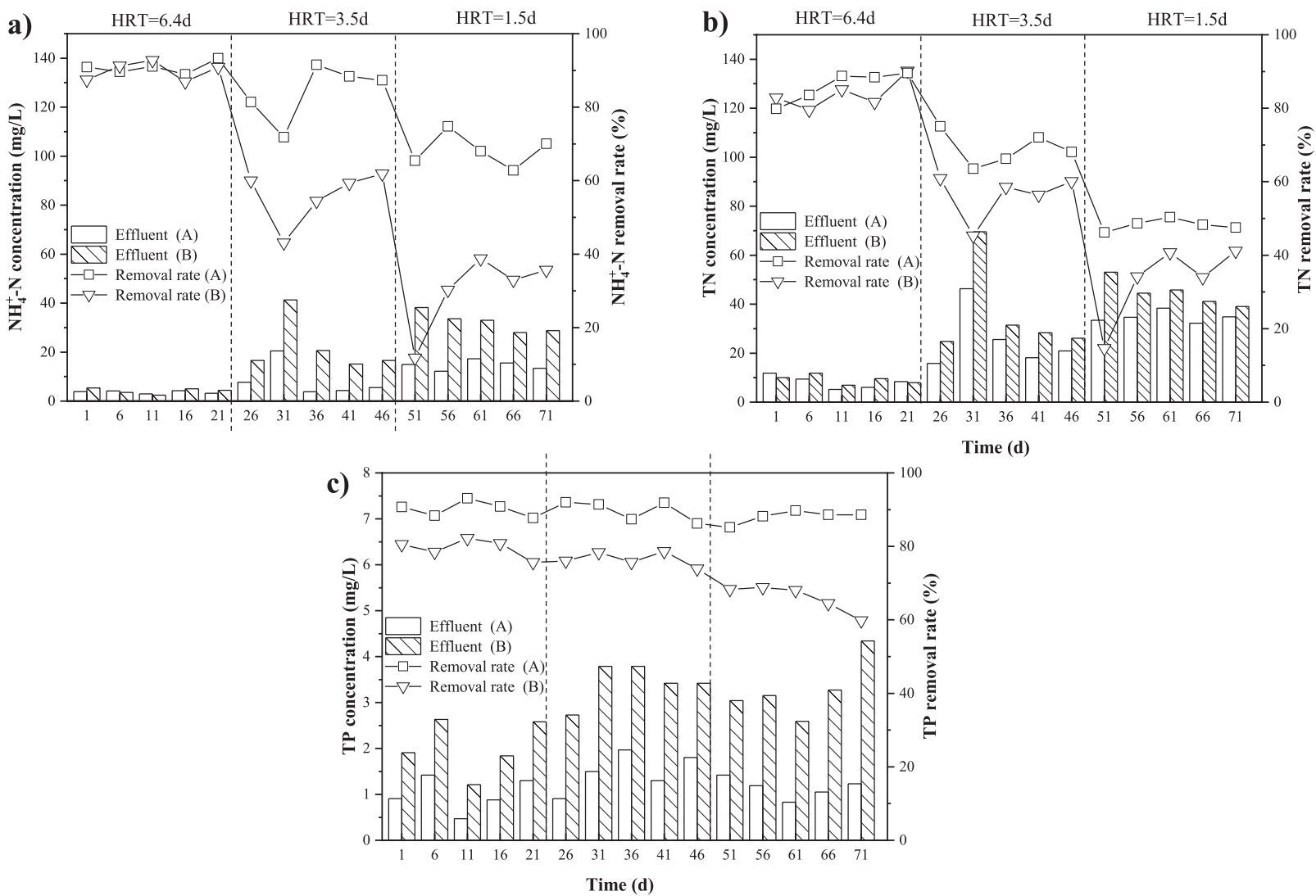

Fig. 2. Pollutant removal ability of system A and B under different HRTs: a) $\mathrm{NH}_{4}^{+}-\mathrm{N}$; b) TN; c) TP.

$1.5 \mathrm{~d}$, the $\mathrm{NH}_{4}^{+}-\mathrm{N}$ and $\mathrm{TN}$ removal rates decreased to about 70 and $50 \%$ in system $\mathrm{A}$ and to $30 \%$ in system B. When the HRT was shortened, organic load and the scouring of the water flow increased, but the reaction time for microorganisms was reduced. Heterotrophic bacteria began to compete for DO with nitrifying bacteria, and nitrification was therefore inhibited, resulting in decreased nitrogen removal.

According to Fig. 2 (a-b), the nitrogen removal performance of system A, containing the homemade ceramsite filler, was more stable and efficient, especially under the condition of a low HRT. The reasons were as follows: on the one hand, the rich pore structure of ceramsite (Fig. 1) facilitates and enhances microbial attachment and multiplication; on the other hand, the homemade ceramsite, with a high silica-aluminate content $\left(\mathrm{Al}_{2} \mathrm{O}_{3}: 24.31 \%, \mathrm{SiO}_{2}: 39.53 \%\right)$, strengthened the physical adsorption and ion exchange of nitrogen compared with the soil filler, which further promoted the mechanism of filler-microbial synergistic adsorption-degradation $[16,21]$.

\section{Effects of HRT on TP removal}

Fig. 2c) shows the variations in TP removal from both systems at different HRTs. At HRTs of 6.4, 3.5, and $1.5 \mathrm{~d}$, the average TP removal rates of system A were $90.15,89.79$, and $88.08 \%$, respectively, which were $10.62,13.27$, and $22.19 \%$ higher than those of system B.
Based on the experimental data, system A maintained a stable and efficient $\mathrm{P}$ removal performance despite the increased TP concentration in the influent at a HRT of $3.5 \mathrm{~d}$. System A had a better impact load resistance than system B, especially at low HRTs.

Mechanisms of TP removal in CWs include plant uptake, microbial degradation, filler adsorption, and chemical precipitation $[22,23]$. The TP removal rate of the system A was stable and remained high under different HRTs, mainly due to the adsorption and deposition of $\mathrm{P}$ by the filler. Previous studies have found that fillers rich in iron and aluminum can achieve high $\mathrm{P}$ removal properties. On the one hand, $\mathrm{Al}^{3+}$ and $\mathrm{Fe}^{3+}$ form insoluble precipitates with $\mathrm{P}$, while on the other hand, $\mathrm{P}$ is adsorbed to $\mathrm{Al}(\mathrm{OH})_{3}$ and $\mathrm{Fe}(\mathrm{OH})_{3}$ colloids $[24,25]$. In this study, the proportions of $\mathrm{Al}^{3+}$ and $\mathrm{Fe}^{3+}$ $\left(\mathrm{Al}_{2} \mathrm{O}_{3}: 24.31 \%, \mathrm{Fe}_{2} \mathrm{O}_{3}: 3.85 \%\right)$ in homemade ceramsite raw materials were relatively high, resulting in a higher $\mathrm{P}$ removal performance. At the end of the experiment, compared with system A, the TP removal rate of system B decreased, indicating that system A had a higher adsorption capacity for $\mathrm{P}$.

\section{Pollutant Removal at Different Packing Heights}

We divided the two systems into bottom (inletsampling port 2), middle (sampling port 2-sampling port 4), and top (sampling port 4-outlet) parts along the inlet depth. When the HRT was $6.4 \mathrm{~d}$, the changes 

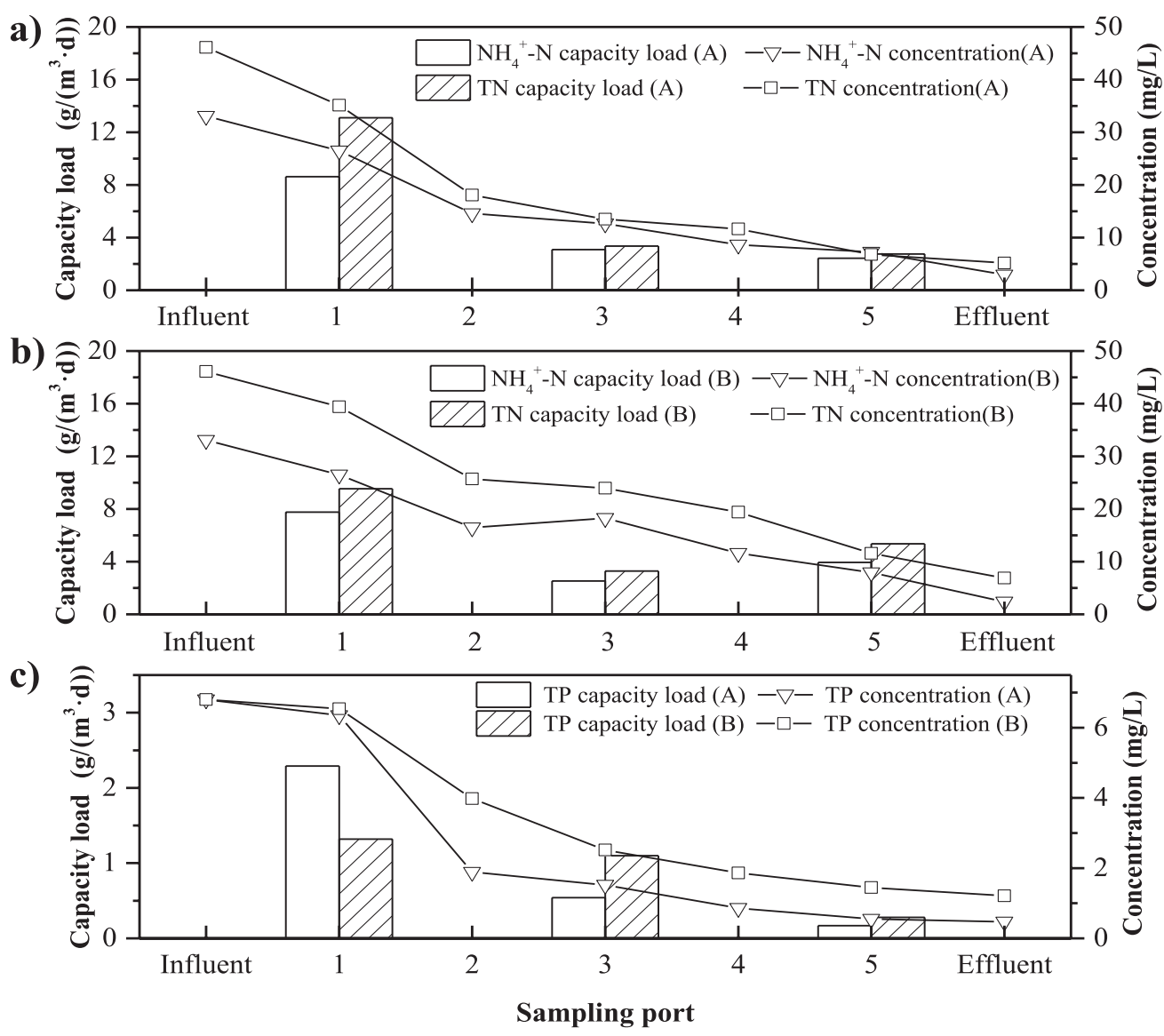

Fig. 3. Pollutant concentration of system $\mathrm{A}$ and $\mathrm{B}$ under various heights: a) $\mathrm{NH}_{4}^{+}-\mathrm{N}$ and $\mathrm{TN}$ in system A; b) $\mathrm{NH}_{4}^{+}-\mathrm{N}$ and $\mathrm{TN}$ in system B; c) TP.

in nutrient concentrations along the influent depth of systems $\mathrm{A}$ and $\mathrm{B}$ are shown in Fig. 3. The pollutant concentrations in both systems decreased with increasing packing height. Most of the nitrogenous substances were removed in the bottom layer, with $\mathrm{NH}_{4}^{+}-\mathrm{N}$ and $\mathrm{TN}$ removal rates of 55.88 and $60.80 \%$, respectively, in system $\mathrm{A}$ and 50.22 and $44.29 \%$ in system $\mathrm{B}$; these values were significantly higher than those in the middle (17.95 and $13.96 \%$ in system A, 14.69 and $13.68 \%$ in system B) and top layers (17.24 and $13.99 \%$ in system A, 27.86 and $27.12 \%$ in system B). The nitrogen volumetric load rates in both systems showed similar trends. The ammonia and total nitrogen volumetric load rates were 8.63, 3.09, 2.44, and 13.10, $3.35,2.76 \mathrm{~g} /\left(\mathrm{m}^{3} \cdot \mathrm{d}\right)$ for system $\mathrm{A}$ and $7.76,2.53,3.94$, and $9.54,3.29,5.35 \mathrm{~g} /\left(\mathrm{m}^{3} \cdot \mathrm{d}\right)$ for system $\mathrm{B}$, respectively. These results may be explained by the filler interception and the adsorption of influent organic matter, leading to high organic matter contents in the filler layer and, consequently, co-adsorption of organic matter and organic nitrogen in the influent. On the other hand, nitrification, denitrification, and simultaneous nitrification and denitrification (with a small amount of DO in the influent) may have occurred at the bottom layer, effectively removing nitrogenous substances. This was verified by the microbial community structure.
The TP removal efficiency was also highest (72.21 and $41.47 \%$ for A and B) at the bottom of the systems. Overall, the TP removal rate in system A (93.09\%) was $10.88 \%$ higher than that in system B, most likely because ceramsite contains large amounts of aluminum and iron, and the hydrolyzed products produce large amounts of flocs, increasing phosphorus removal performance [25].

\section{Packing Performance}

A combination of physical, chemical, and biological methods have been used to remove pollutants (including filtration, adsorption, and biodegradation) [26]. The physical and purification properties of homemade ceramsite and other fillers previously studied are shown in Tables 2 and 3. Based on the results, the homemade ceramsite showed better physical properties (Fig. 1, porosity and specific surface area were $5.24 \mathrm{~m}^{2} \cdot \mathrm{g}^{-1}$ and $45.0 \%$, respectively) and purification properties $\left(\mathrm{NH}_{4}^{+}-\mathrm{N}, \mathrm{TN}\right.$, and TP removal rates were 90.78, 86.04, and $90.15 \%$, respectively), which are closely related to the composition of the ceramsite and the firing conditions (sintering temperature and time).

Like solid wastes such as fly ash, waste brick, and titania-containing blast furnace slag, homemade 
Table 2. Comparison of physical properties of different ceramsite.

\begin{tabular}{|c|c|c|c|c|c|}
\hline \multirow{2}{*}{ Raw Material } & \multirow{2}{*}{$\begin{array}{l}\text { Specific surface } \\
\text { area } /\left(\mathrm{m}^{2} \cdot \mathrm{g}^{-1}\right)\end{array}$} & \multirow{2}{*}{$\begin{array}{c}\text { Porosity } \\
(\%)\end{array}$} & \multicolumn{2}{|c|}{$\begin{array}{c}\text { Component proportion } \\
(\%)\end{array}$} & \multirow[t]{2}{*}{ References } \\
\hline & & & $\mathrm{Al}_{2} \mathrm{O}_{3}$ & $\mathrm{Fe}_{2} \mathrm{O}_{3}$ & \\
\hline Coal fly ash, waterworks sludge, and oyster shell & - & - & 21.48 & & [27] \\
\hline- & - & 31.3 & 16.23 & 7.84 & [21] \\
\hline- & 2.17 & - & - & - & {$[28]$} \\
\hline Bentonite, red mud, and pine sawdust & - & - & 13.95 & - & [29] \\
\hline Drinking-water treatment sludge and clay & 4.85 & 52.0 & - & - & \multirow{2}{*}{ [30] } \\
\hline- & 2.62 & 44.5 & - & - & \\
\hline $\begin{array}{l}\text { Sewer pipe sediments, river bed sediments, urban water supply } \\
\text { treatment sludge, and wastewater treatment plant excess sludge }\end{array}$ & 0.50 & - & 8.84 & 35.78 & {$[31]$} \\
\hline $\begin{array}{c}\text { Coal fly ash, drinking waterworks sludge, clay and glass } \\
\text { powder }\end{array}$ & 5.24 & 45.0 & 24.31 & 3.85 & This study \\
\hline
\end{tabular}

Table 3. Comparison of purification performance of $\mathrm{CW}$ with different fillers.

\begin{tabular}{|c|c|c|c|c|c|}
\hline \multirow{2}{*}{ Filler } & \multirow{2}{*}{$\begin{array}{c}\text { Influent concentration } \\
(\mathrm{mg} / \mathrm{L})\end{array}$} & \multicolumn{3}{|c|}{ Removal performance } & \multirow{2}{*}{ References } \\
\hline & & $\mathrm{NH}_{4}^{+}-\mathrm{N}$ & $\mathrm{TN}$ & TP & \\
\hline \multirow{2}{*}{$\begin{array}{l}\text { Composite fillers (sand and Ti-bearing blast } \\
\text { furnace slag) }\end{array}$} & Influent & $40.07 \pm 8.26$ & $54.2 \pm 12.55$ & $4.24 \pm 0.87$ & \multirow{4}{*}[32]{} \\
\hline & Removal rate & 77.54 & 70.77 & 98 & \\
\hline Composite fillers (sand and stone) & Removal rate & 77.22 & 60.63 & 96 & \\
\hline $\begin{array}{l}\text { Composite fillers (sand and the converter } \\
\text { steelmaking slag) }\end{array}$ & Removal rate & 59.23 & 53.02 & 98 & \\
\hline \multirow{2}{*}{ Waste brick } & Influent & $7.11-12.31$ & $9.54-15.48$ & $1.24-2.03$ & \multirow{2}{*}[23]{} \\
\hline & Removal rate & 72.10 & 56.53 & 91.55 & \\
\hline \multirow{2}{*}{$\begin{array}{l}\text { Composite fillers (soil, bamboo charcoa, and } \\
\text { gravelstone) }\end{array}$} & Influent & $38-97$ & $59-134$ & $3.4-13.9$ & \multirow{3}{*}{ [33] } \\
\hline & Removal rate & About 75 & 69.2 & 69.2 & \\
\hline $\begin{array}{c}\text { Composite fillers (soil, limestone, and grav- } \\
\text { elstone) }\end{array}$ & Removal rate & - & 50.1 & 55.2 & \\
\hline \multirow{2}{*}{ Composite fillers (ceramsite and gravel) } & Influent & $7.14-20.13$ & $21.49-34.27$ & $1.2-3.20$ & \multirow{2}{*}[34]{} \\
\hline & Removal rate & 53.1 & 45.1 & 69.6 & \\
\hline \multirow{2}{*}{$\begin{array}{l}\text { Composite fillers (gravel, ceramsite, zeolite, } \\
\text { and red soil) }\end{array}$} & Influent & 4.74 & 25.55 & 13.39 & \multirow{2}{*}[35]{} \\
\hline & Removal rate & 73 & 76 & 72 & \\
\hline \multirow{2}{*}{ Shale ceramisite } & Influent & 49.3 & 53.9 & 5.41 & \multirow{2}{*}{ [28] } \\
\hline & Removal rate & 64.9 & 47.2 & 27.46 & \\
\hline \multirow{2}{*}{ Composite fillers (ceramisite and soil) } & Influent & $44.96 \pm 5.80$ & $68.45 \pm 11.53$ & $11.36 \pm 2.35$ & \multirow{2}{*}{ This study } \\
\hline & Removal rate & 90.78 & 86.04 & 90.15 & \\
\hline
\end{tabular}

ceramsite made of clay, waterwoks sludge, and fly ash can be effectively used in sewage treatment.

\section{Microbial Community Structure}

The process of biological wastewater treatment is closely related to the microbial community structure
$[36,37]$. In CW systems, the stability of wastewater treatment can be improved with a higher microbial diversity [38]. The physicochemical properties of the wetland filler affect the gene expression of attached microorganisms, thus influencing biofilm formation and community structure. Therefore, it is of great significance to explore the microbial community 
Table 4. Alpha diversity index of microorganisms.

\begin{tabular}{|c|c|c|c|c|c|c|}
\hline Sample name & A1 & A3 & A5 & B1 & B3 & B5 \\
\hline Observed species & 4613 & 3966 & 3974 & 2705 & 2354 & 3224 \\
\hline Shannon & 10.532 & 9.272 & 9.62 & 8.667 & 7.75 & 9.257 \\
\hline Chao1 & 5157.896 & 4425.672 & 4520.995 & 3067.799 & 2674.25 & 3597.826 \\
\hline Ace & 5362.065 & 4698.264 & 4785.649 & 3270.39 & 2879.386 & 3754.283 \\
\hline Goods coverage & 0.979 & 0.981 & 0.98 & 0.986 & 0.988 & 0.985 \\
\hline
\end{tabular}

structure in different fillers systems (here, A and B) for optimizing CW fillers.

At the level of $97 \%$ similarity, the alpha diversity indices of samples A and B were obtained as shown in Table 4, and the number of species followed the order $\mathrm{A} 1>\mathrm{A} 5>\mathrm{A} 3>\mathrm{B} 5>\mathrm{B} 1>\mathrm{B} 3$. Both Ace and Chaol indices followed the order $\mathrm{A} 1>\mathrm{A} 5>\mathrm{A} 3>\mathrm{B} 5>\mathrm{B} 1>\mathrm{B} 3$, where as order of the Shannon index was $\mathrm{A} 1>\mathrm{A} 5>\mathrm{A} 3>\mathrm{B} 5>\mathrm{B} 1>\mathrm{B} 3$. Databased on these data, total species number and diversity were higher in system A than in system B; the microbial community was more stable in system A.

The relative abundance distribution of species at the genus level (top 30) is shown in Fig. 4. The genera of nitrifying bacteria included Stenotrophomonas, unidentified Nitrospiraceae, unidentified Nitrosomonadaceae, Sphingomonas, Pseudomonas, and Acinetobacter [39-41]. The proportions of nitrifying bacteria in each filler layer of $\mathrm{CW}$ followed the order A1 $(6.189 \%)>\mathrm{A} 3 \quad(5.885 \%)>\mathrm{B} 5 \quad(4.698 \%)>\mathrm{B} 1 \quad(2.587 \%)>\mathrm{B} 3$ $(2.322 \%)>A 5(0.879 \%)$. Overall, compared with system $\mathrm{B}$, system A had more nitrifying bacterial genera and, therefore, a higher nitrogen removal performance. As in both systems, plant size, packing volume, and influent were similar, we infer that the mixture of ceramsite and soil may have facilitated the diffusion of influent oxygen (A1), plant reoxygenation (A3), and the mass transfer of pollutants. Both nitrification occurrence and nitrifying bacterial content were higher in A3 than in A5, indicating that the plant root reoxygenation may be higher than that of the atmosphere, which also occurs in CWs with surface flow and horizontal subsurface flow [42]. In addition, Stenotrophomonas, Pseudomonas, Acinetobacter, and Sphingomonas are aerobic denitrifiers, enabling simultaneous nitrification

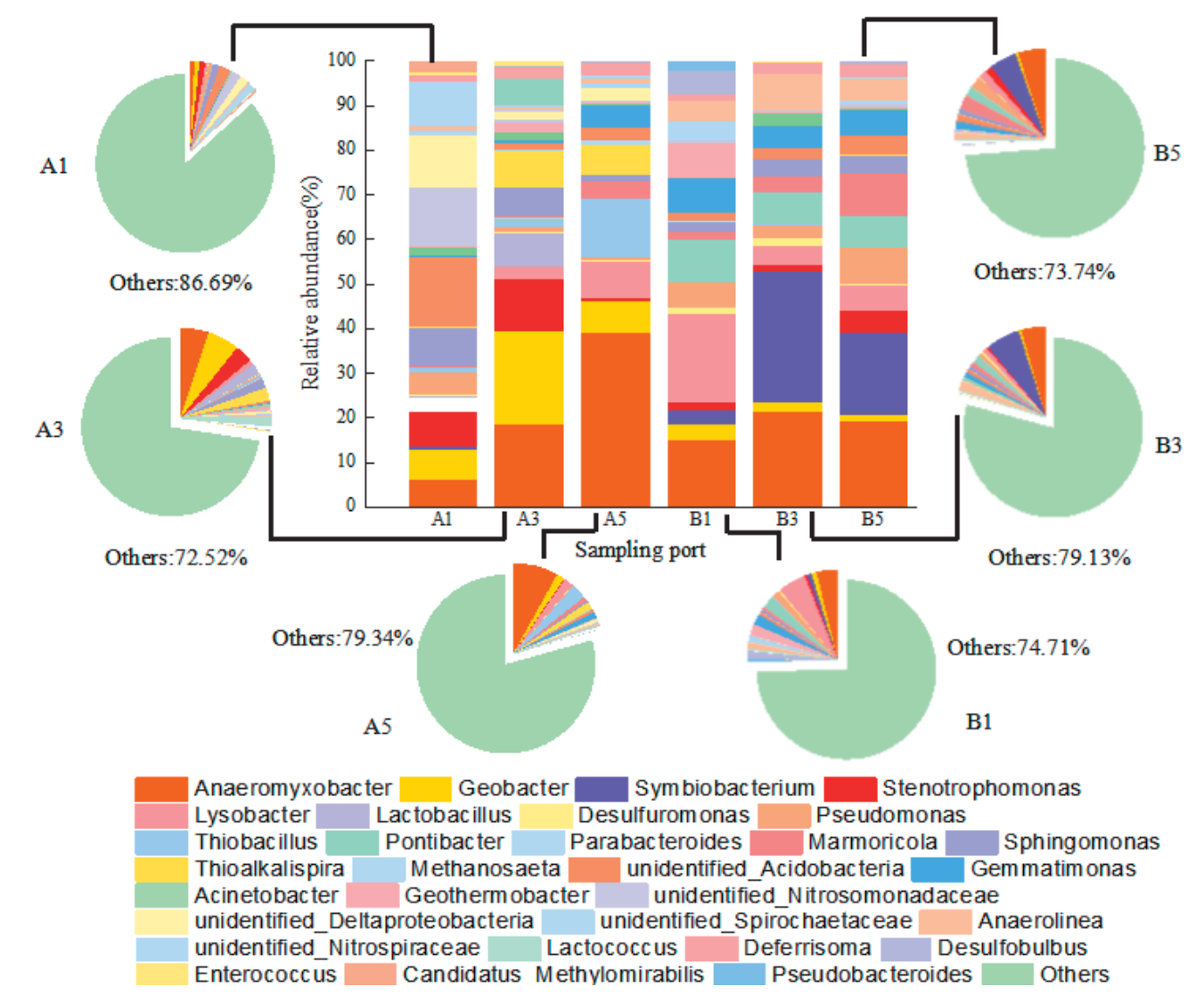

Fig. 4. Bacterial communities (top 30) revealed by $16 \mathrm{~S}$ rRNA gene Hiseq sequencing at the genus level. 
and denitrification [39, 43]. The middle layer of system A (A3: 7.972\%) and the top layer of system B (B5: 4.606\%) had higher amounts of denitrifying bacteria. The presence of autotrophic denitrifying bacteria (Thioalkalispira) as well as Candidatus Methylomirabilis and Anaeromyxobacter anaerobicus, which can use nitrite and nitrous nitrogen as electron acceptors, also promotes denitrification in such systems [44-46]. The proportion of the polyphosphorous bacterium Gemmatimonas was higher in system B $(4.466 \%)$ than in system A $(1.255 \%)$, whereas the actual TP removal rate showed the opposite pattern, indicating that the $\mathrm{P}$ removal performance of the ceramsite-soil filler was mainly physicochemical [47]

\section{Conclusions}

1. At longer HRTs, the removal efficiencies for $\mathrm{NH}_{4}^{+}-\mathrm{N}$ and $\mathrm{TN}$ in both $\mathrm{CW}$ systems were good; removal performance decreased with shorter HRTs. When the HRT was short, the $\mathrm{NH}_{4}^{+}-\mathrm{N}$ and TN removal performances in the ceramsite-soil filler wetland were significantly higher than those in the soil filler wetland. The addition of homemade ceramsite enhanced microbial degradation and increased adsorption performance.

2. The TP removal efficiency of both $\mathrm{CW}$ systems was not affected by HRT, and the main mechanism of $\mathrm{P}$ removal was the adsorption of $\mathrm{P}$ through the physical and chemical interaction of ceramsite and soil. Under various HRTs, the TP removal efficiency of the ceramsite-soil filler wetland was significantly higher than that of the soil wetland system.

3. With increasing packing height, the concentrations of pollutants $\left(\mathrm{NH}_{4}^{+}-\mathrm{N}, \mathrm{TN}\right.$, and TP) in both systems decreased, and most of the pollutants were removed at the bottom layer of the systems $(0-145 \mathrm{~mm})$.

4. In terms of microbial community structure and genus level, compared with the soil filler wetland, the ceramsite-soil filler wetland had a higher diversity and more nitrobacteria genera, which were more prominent in the bottom layer.

\section{Acknowledgements}

This work was supported by National Key R\&D Program Specialized "Integrated Technology and Application Demonstration of Rural Water Supply and Drainage in Typical Water-Deficit Areas in the West" (2016YFC0400703-3), the PhD start-up fund of Xi'an university of science and technology (Grant No. 2018QDJ005), the open fund of State Key Laboratory of Pollution Control and Resource Reuse (Grant No. PCRRF18014), and the National Natural Science Foundation of China (Grant No. 51708447).

\section{Conflict of Interest}

The authors declared no conflict of interest.

\section{References}

1. GAO H., ZHOU C.B., LI F., HAN B.L., LI X.X. Economic and environmental analysis of five Chinese rural toilet technologies based on the economic input-output life cycle assessment. Journal of Cleaner Production, 163, S379, 2017.

2. XIA R., PENG Y.T., ZHONG S., TU L.J., XIE Y.S., ZHANG L.S. Performance of the Iron-Caron Coupling Constructed Wetland for Rural Sewage Treatment. IOP Conference Series: Earth and Environmental Science, 51 (1), 012016, 2017.

3. KUMAR S., DUTTA V. Efficiency of Constructed Wetland Microcosms (CWMs) for the Treatment of Domestic Wastewater Using Aquatic Macrophytes. Environmental Biotechnology: For Sustainable Future; SOBTI R.C., ARORA N.K., KOTHARI R., Eds., Springer: Singapore, pp. 287, 2019.

4. CARVALHO P.N., ARIAS C.A., BRIX H. Constructed wetlands for water treatment: New developments. Water, 9 (6), 2017.

5. LI X., LI Y.Y., LV D.Q., LI Y., WU J.S. Nitrogen and phosphorus removal performance and bacterial communities in a multi-stage surface flow constructed wetland treating rural domestic sewage. Science of the Total Environment, 709, 136235, 2020.

6. ZHANG X.Y., PENG D.C., WAN Q., JU K., WANG B.B., PEI L.Y., HOU Y.P. Changing the nutrient source from ammonia to nitrate: Effects on heterotrophic bacterial growth in wastewater. Polish Journal of Environmental Studies, 29(2), 1473, 2020.

7. WU Y.H., HAN R., YANG X.N., ZHANG Y.K., ZHANG R.D. Long-term performance of an integrated constructed wetland for advanced treatment of mixed wastewater. Ecological Engineering, 99, 91, 2017.

8. JIANG Y.H., LI Y., ZHANG Y., ZHANG X.L. Effects of HRT on the efficiency of denitrification and carbon source release in constructed wetland filled with bark. Water Science and Technology, 75 (12), 2908, 2017.

9. ZHANG C.B., LIU W.L., WANG J., GE Y., GU B.H., CHANG J. Effects of plant diversity and hydraulic retention time on pollutant removals in vertical flow constructed wetland mesocosms. Ecological Engineering, 49, 244, 2012.

10. SEHAR S., AAMIR R., NAZ I., ALI N., AHMED S. Reduction of Contaminants (Physical, Chemical, and Microbial) in Domestic Wastewater through Hybrid Constructed Wetland. ISRN Microbiology, 2013, 1, 2013.

11. IMBURU C., KIPKEMBOI J., KIMWAGA R. Impact of substrate type, depth and retention time on organic matter removal in vertical subsurface flow constructed wetland mesocosms for treating slaughterhouse wastewater. Physics and Chemistry of the Earth, 114, 102792, 2019.

12. MENG F.C., FENG L.J., YIN H.J., CHEN K.Q., HU G.H., YANG G.F., ZHOU J.H. Assessment of nutrient removal and microbial population dynamics in a non-aerated vertical baffled flow constructed wetland for contaminated water treatment with composite biochar addition. Journal of Environmental Management, 246, 355, 2019. 
13. CHEN X.F., HUANG X.L., ZHANG K., WU C.X. Feasibility of using plastic wastes as constructed wetland substrates and potential for pharmaceuticals and personal care products removal. Journal of Environmental Science and Health, 55 (10), 1241, 2020.

14. MATEUS D.M.R., PINHO H.J.O. Evaluation of solid waste stratified mixtures as constructed wetland fillers under different operation modes. Journal of Cleaner Production, 253, 119986, 2020.

15. SI Z.H., SONG X.S., WANG Y.H., CAO X., WANG Y.F., ZHAO Y.F., GE X.Y., SAND W. Untangling the nitrate removal pathways for a constructed wetland- sponge iron coupled system and the impacts of sponge iron on a wetland ecosystem. Journal of Hazardous Materials, 393, 122407, 2020.

16. XIA Z.G., LIU G.C., SHE Z.L., GAO M.C., ZHAO Y.G., GUO L., JIN C.J. Performance and bacterial communities in unsaturated and saturated zones of a vertical-flow constructed wetland with continuous-feed. Bioresource Technology, 315, 123859, 2020.

17. WANG Y.N., YANG J.H., XU H., LIU C.W., SHEN Z., HU K. Preparation of ceramsite based on waterworks sludge and its application as matrix in constructed wetlands. International Journal of Environmental Research and Public Health, 16 (15), 2637, 2019.

18. WAN Q., HAN Q.J., ZHANG X.Y., JU K., ZHAO Z.X., LEI R., PENG B. Preparation and Performance Optimization of Ceramsites Using Waste Sludge. Bulletin of the Chinese Ceramic Society, 38( 4), 1228, 2019 [In Chinese].

19. CLESCERI L.S., GREENBERG A.E., EATON A.D. Standard Methods for the Examination of Water and Wastewater. $20^{\text {th }}$, ed. American Public Health Association: Washington, DC, USA, pp. 2-54-4-148, 1998.

20. CAPORASO J.G., LAUBER C.L., WALTERS W.A., BERG-LYONS D., HUNTLEY J., FIERER N., OWENS S.M., BETLEY J., FRASER L., BAUER M., GORMLEY N., GILBERT J.A., SMITH G., KNIGHT R. Ultra-highthroughput microbial community analysis on the Illumina HiSeq and MiSeq platforms. ISME Journal, 6 (8), 1621, 2012.

21. GAO J.Q., YANG L., ZhONG R., CHEN Y., ZHANG J.S., GAO J.L., CAI M., ZHANG J.L. Comparison of nitrogen and phosphorus removal efficiency between two types of baffled vertical flow constructed wetlands planted with Oenanthe Javanica. Water Science and Technology, 81 (9), 2023, 2020.

22. TANNER C.C., SUKIAS J.P.S., UPSDELL M.P. Substratum phosphorus accumulation during maturation of gravel-bed constructed wetlands. Water Science and Technology, 40 (3), 147, 1999.

23. ZHANG G.Z., MA K., ZHANG Z.X., SHANG X.B., WU F.P. Waste Brick as Constructed Wetland Fillers to Treat the Tail Water of Sewage Treatment Plant. Bulletin of Environmental Contamination and Toxicology, 104 (2), 273, 2020.

24. LI J.K., LIANG Z., GAO Z.X., LI Y.J. Experiment and simulation of the purification effects of multi-level series constructed wetlands on urban surface runoff. Ecological Engineering, 91, 74, 2016.

25. JIANG C., JIA L.Y., ZHANG B., HE Y.L., KIRUMBA G. Comparison of quartz sand, anthracite, shale and biological ceramsite for adsorptive removal of phosphorus from aqueous solution. Journal of Environmental Sciences, 26 (2), 466, 2014.
26. CARRASCO-ACOSTA M., GARCIA-JIMENEZ P., HERRERA-MELIAN J.A., PENATE-CASTELLANO N., RIVERO-ROSALES A. The effects of plants on pollutant removal, clogging, and bacterial community structure in palm mulch-based vertical flow constructedwetlands. Sustainability, 11 (3), 632, 2019.

27. CHENG G., LI Q.H., SU Z., SHENG S., FU J. Preparation, optimization, and application of sustainable ceramsite substrate from coal fly ash/waterworks sludge/oyster shell for phosphorus immobilization in constructed wetlands. Journal of Cleaner Production, 175, 572, 2018.

28. TAN X., YANG Y.L., LIU Y.W., LI X., FAN X.Y., ZHOU Z.W., LIU C.J., YIN W.C. Enhanced simultaneous organics and nutrients removal in tidal flow constructed wetland using activated alumina as substrate treating domestic wastewater. Bioresource Technology, 280 (100), 441, 2019.

29. WANG Y.T., GONG S.Y., LI Y.Z., LI Z., FU J. Adsorptive removal of tetracycline by sustainable ceramsite substrate from bentonite/red mud/pine sawdust. Scientific Reports, 10 (1), $1,2020$.

30. CHEN S.Q., CHEN Y., PEI H.Y., HOU Q.J. Biofilm development dynamics and pollutant removal performance of ceramsite made from drinking-water treatment sludge. Water Environment Research, 91 (7), 616, 2019.

31. WANG J.L., ZHAO Y.L., ZHANG P.P., YANG L.Q., XU H.A., XI G.P. Adsorption characteristics of a novel ceramsite for heavy metal removal from stormwater runoff. Chinese Journal of Chemical Engineering, 26 (1), 96, 2018.

32. XU R., ZHANG Y., LIU R., CAO Y., WANG G.X., JI L.C., XU Y.F. Effects of different substrates on nitrogen and phosphorus removal in horizontal subsurface flow constructed wetlands. Environmental Science and Pollution Research, 26 (16), 16229, 2019.

33. LU S.B., ZHANG X.L., WANG J.H., PEI L. Impacts of different media on constructed wetlands for rural household sewage treatment. Journal of Cleaner Production, 127, 325, 2016.

34. ABBASI H.N., XIE J., HUSSAIN S.I., LU X.W. Nutrient removal in hybrid constructed wetlands: Spatial-seasonal variation and the effect of vegetation. Water Science and Technology, 79 (10), 1985, 2019.

35. HUANG X.F., LUO Y., LIU Z.L., ZHANG C.L., ZHONG H., XUE J.J., WANG Q.G., ZHU Z.P., WANG C. Influence of two-stage combinations of constructed wetlands on the removal of antibiotics, antibiotic resistance genes and nutrients from goose wastewater. International Journal of Environmental Research and Public Health, 16(20), 1, 2019.

36. SAEED T., SUN G. A review on nitrogen and organics removal mechanisms in subsurface flow constructed wetlands: Dependency on environmental parameters, operating conditions and supporting media. Journal of Environmental Management, 112, 429, 2012.

37. ZHOU Y.L., JIANG H.L., CAI H.Y. To prevent the occurrence of black water agglomerate through delaying decomposition of cyanobacterial bloom biomass by sediment microbial fuel cell. Journal of Hazardous Materials, 287, 7, 2015.

38. BERNARDES F.S., HERRERA P.G., CHIQUITO, G.M., MORALES M.F., CASTRO, A.P., PAULO, P.L. Relationship between microbial community and environmental conditions in a constructed wetland system treating greywater. Ecological Engineering, 139, 105581, 2019. 
39. LU J., ZHANG Y.X., WU J., WANG J.H. Nitrogen removal in recirculating aquaculture water with high dissolved oxygen conditions using the simultaneous partial nitrification, anammox and denitrification system. Bioresource Technology, 305, 123037, 2020.

40. LI D., LIANG X.H., LI Z.W., JIN Y., ZHOU R.Q., WU C.D. Effect of chemical oxygen demand load on the nitrification and microbial communities in activated sludge from an aerobic nitrifying reactor, 11 (2), 137, 2010.

41. MA Q., QU Y.Y., SHEN W.L., ZHANG Z.J., WANG J.W., LIU Z.Y., LI D.X., LI H.J., ZHOU J.T. Bacterial community compositions of coking wastewater treatment plants in steel industry revealed by Illumina highthroughput sequencing. Bioresource Technology, 179, 436, 2015.

42. LIU H.Q., HU Z., ZHANG J., NGO H.H., GUO W.S., LIANG S., FAN J.L., LU S.Y., WU H.M. Optimizations on supply and distribution of dissolved oxygen in constructed wetlands: A review. Bioresource Technology, 214, 797, 2016.

43. LANG X.D., LI Q.W., XU Y.C., JI M.M., YAN G.X., GUO S.H. Aerobic denitrifiers with petroleum metabolizing ability isolated from caprolactam sewage treatment pool. Bioresource Technology, 290, 121719, 2019.
44. XIA Z.G., WANG Q., SHE Z.L., GAO M.C., ZHAO Y.G., GUO L., JIN C.J. Nitrogen removal pathway and dynamics of microbial community with the increase of salinity in simultaneous nitrification and denitrification process. Science of the Total Environment, 697, 134047, 2019.

45. AGUILAR-RANGEL E.J., PRADO B.L., VASQUEZMURRIETA M.S., LOS SANTOS P.E., SIEBE C., FALCON L.I., SANTILLAN J., ALCANTARAHERNANDEZ R.J. Temporal analysis of the microbial communities in a nitrate-contaminated aquifer and the co-occurrence of anammox, n-damo and nitrous-oxide reducing bacteria. Journal of Contaminant Hydrology, 234, 103657, 2020.

46. ROTH H., GALLO S., BADGER P., HILLWIG M. Changes in microbial communities of a passive coal mine drainage bioremediation system. Canadian Journal of Microbiology, 65 (10), 775, 2019.

47. JI B., ZHU L., WANG S.Y., QIN H., MA Y.Q., LIU Y. A novel micro-ferrous dosing strategy for enhancing biological phosphorus removal from municipal wastewater. Science of the Total Environment, 704, 135453, 2020. 